\title{
Letting Go of Narrative History: The Linearity of Time and the Art of Recounting the Past
}

Ari Helo

\section{(2) OpenEdition}

\section{Journals}

Electronic version

URL: https://journals.openedition.org/ejas/11648

DOI: 10.4000/ejas.11648

ISSN: 1991-9336

Publisher

European Association for American Studies

\section{Electronic reference}

Ari Helo, "Letting Go of Narrative History: The Linearity of Time and the Art of Recounting the Past", European journal of American studies [Online], 11-2 | 2016, document 15, Online since 11 August 2016 connection on 08 July 2021. URL: http://journals.openedition.org/ejas/11648 ; DOI: https://doi.org/ 10.4000/ejas. 11648

This text was automatically generated on 8 July 2021.

Creative Commons License 


\title{
Letting Go of Narrative History: The Linearity of Time and the Art of Recounting the Past
}

\author{
Ari Helo
}

\section{Introduction}

1 I once got into a debate with a group of history students about the narrative character of history. ${ }^{1}$ They had difficulty grasping my objections, because I questioned the notion of history as a narrative, but refused to hold that it is something else entirely. There is much truth to the view that historians do not simply offer us more or less true representations of the past, but rather create history out of the past, as Alun Munslow among many others insists. ${ }^{2}$ Yet, instead of engaging in endless erudite disagreements about the epistemologically valid view of reality, let alone past reality, one would do better to view history as historians' ongoing discourse about the best explanation of any given past phenomenon.

2 This essay aims to set aside needless metaphysics about the inherently narrative character of history, a penchant that leads to confusion about the methodological basics of historical research. This entails refuting two-still surprisingly commonmisunderstandings about historical research: the first one is that history is about contributing to a presumed metanarrative of humankind; and the second is that our only access to the past is through some more or less mythical notion of telling stories about it. For the high priest of the so-called linguistic turn in historiography, Hayden White, the notion that as an entity history may well lack any rationale is rather the starting point for a serious study of historiography than the result of it. ${ }^{3}$ While holding that the narrative form of meaning production is the determinant factor of all historiography, White at the same time acknowledges that not all historical studies are narratives with "well-marked beginning, middle, and end phases."4 
3 My point is not to prove or disprove the views of White or any other theorist committed to the narrative character of history or historiography. On the practical level all that a historian needs to accomplish is to explain a given past phenomenon. When a historian asks, for example, what the Aristotelian conception of justice was, and manages to answer the question, the work is completed. Most likely, the historian would claim that the Aristotelian concept of justice had little to do with the modern notion of the equal rights of all human beings. Rather, it drew on the assumption that every free man should be appropriated his due share of rights and privileges according to his virtuous capacities to contribute to the common good of the polis. The rights of merchants, slaves, women, and children were excluded from this sphere of public justice, which was concerned solely with the relations among the male citizenry. Whether or not this purely tentative description is even close to Aristotle's view, anyone can understand such a conception of justice, even if we cannot subscribe to it any more. Let me add that there is nothing anachronistic in recounting Aristotle's notion of justice in modern terms, providing the historian does not attempt to portray it as merely a forerunner of the modern one. ${ }^{5}$ History is about explaining the past in the present.

4 Thinking of history as knowledge of the past, and possibly of nothing else, makes it easier for us to grasp the basics of historical research. ${ }^{6}$ No matter what magnificent reforms politicians manage to put through, it is the historian who eventually decides what reforms are important enough to be noticed in the book of history. Consider, in contrast, if we historians were to accept a politician's use of history in the service of his goals for the future: a good example is President Obama's 2009 Inaugural address, in which he asserted that "those who cling to power through corruption and deceit and the silencing of dissent ... are on the wrong side of history." There appears to be a right side of history that Obama sees as more or less equivalent to the American way of thinking, given that, according to him, such values as "hard work and honesty, courage and fair play, tolerance and curiosity, loyalty and patriotism ... have been the quiet force of progress throughout our history." ${ }^{17}$ For Obama, American history is progressive, and in order to be on its right side, one should assume a progressive attitude to it.

5 It is almost too easy to contextualize some of Obama's political initiatives, say Obamacare (the Affordable Care Act), in terms of such a progressive conception of history. As early as 1912, the Progressive Party presidential candidate Theodore Roosevelt suggested adopting nationwide health insurance. As for Obama making progressive history with his initiative, one could even claim that in historical hindsight he is about to turn Roosevelt's progressive initiative into an anticipation of this later progressive event, unlike Bill Clinton, who failed in a similar effort. The role of the practicing historian in all this would be that of a mere clerk chronicling the progressive national master narrative as it unfolds over time. Yet with every notion of there actually being a story we are also faced by the question of what its ultimate purpose would be (for every story has a telos) -and we do not know for certain that history has one. $^{8}$

6 This is why I suggest viewing history, not as a narrative, but as an art of recounting the past, based on the following maxims: 1. The practicing historian alone makes history, because s/he writes it. 2. Everything the historian explains about the past rests on the notion of linearity of time. 3. The accounts vary only according to the questions one poses about a past phenomenon. 
7 In the following I will discuss a number of distinctions useful for clarifying these maxims, none of which aims at refuting the narrative character of history, given that the point is only to avoid getting caught up in its confusing repercussions regarding the actual job of a historian. First, although history writing is no less a matter of meaning production than is any other use of language, it is worth considering it not as a discourse-in the sense of an event of language alone-but as an ongoing discussion between historians (and other interested parties) over the best account of any given past phenomenon. Second, one should not confuse our shared experience of temporality with any particular traditional framework for grasping the meaning of time, be that the ancient, cyclical notion of time, the Christian conception of meaningful time, or the Marxian view of history, to name but a few. History can be viewed solely as knowledge of the past. Thirdly, it is important not to confuse the politics of the past with the politics of the present. Were we to have a genuinely common understanding of the present condition of all humankind, we would have no political disagreements on where to go from here. Given that we, in fact, disagree on where exactly history has brought us, the safest epistemological position for a historian is that the past is just as messy as our own present. Fourthly, one should distinguish between explaining the meaning of a certain phenomenon in the past and its possible historical significance for the present. The significance of a past phenomenon lies only in the present, but that significance does not need to derive from any preconception of history as a metaphysical whole. Once these distinctions are properly understood, one has a solid rationale to call the profession of a historian the art of recounting the past. In my conclusion I shall propose an answer to the question whether it is any use to study history.

\section{History and Meaning Production}

8 According to the paradigmatic notion of semiotics and communication studies, meanings are always produced. We constantly create our human reality as communicable by signifying things around us. Our reality is, to a large extent, made up of those meanings we apparently only reduce from a presumably pre-existent reality. How we understand time is an important part of this ongoing meaning production. Hayden White's The Content of the Form (1987) begins with relating how modern history writing was born by distinguishing itself from both medieval annals and chronicles by assuming the narrative form of meaning production. Annals were mere lists of any set of events, and while chronicles connected the events as logically following from one another, they lacked a closing statement of their actual meaning. By contrast, the historical narrative could identify a given "set of events as belonging to the same order of meaning."' Some kind of closure is immanent to this prioritized form of meaning production shaping a given series of events as if preordained by their end result. The very title of White's book implies that narrative as the particular form of meaning production in history largely predetermines its referential content, namely, what the events in question stand for.

9 There is a simpler way to view the form and content relation as relevant to the academic study of history. History does not necessarily comprise a narrative. Rather, historical discourse is a discourse between historians about what kind of accounts are fruitful about this or that particular past phenomenon. For this ongoing discussion 
there is a time-honored form to keep the discussants aware of history as a field of research problems. It consists of an introduction, where one states a research problem; then follows the report on the evidence; and then the conclusion, where the solution to the problem is given. The formal or implicit "content" of the introduction is that there is, indeed, a research problem, while the formal content of the conclusion is that the problem has been solved, or at least clarified. Whether the report on the evidence (the middle) is a narrative account of the evidence or an analysis of it is more a matter of opting for the most efficient way of communication than of anything else.

10Anyone familiar with Roman Jacobson's thesis on the levels of communication may discern referential, conative, phatic, and other such uses of language in historical explanations as well. For example, Ernest Gellner's classic book, Nations and Nationalism (1983), abounds in such oddly irrelevant witticisms as that "every girl ought to have a husband, preferably her own." Gellner's aim of keeping contact with the reader (the phatic function) is similarly conspicuous in many key formulations of his actual thesis, such as that "nations can be defined only in terms of the age of nationalism, rather than, as you might expect, the other way round." ${ }^{10}$

11 No matter how interesting these linguistic aspects of history writing may be, there is no need to equate the study of history with the study of sheer meaning production. Let me illustrate this by Hayden White's somewhat confusing article "The Context in the Text: Method and Ideology in Intellectual History." Given that the topic is method in intellectual history, White unexpectedly provides us with a purely literary analysis of The Education of Henry Adams, a book awarded the Pulitzer in 1919 shortly after the author's death. Focusing on a variety of topics in Adams's text, such as its "rhetoric of asceticism and evasion," its implications about the "nature of all signification," and the author's "fractured persona," White eventually considers all these issues as symptomatic of one or another aspect of meaning production itself. His "unpacking" of this literary work aims at precisely what literary studies traditionally do, namely enriching our understanding of the particular textual sample under scrutiny: "Far from reducing the work," he states, "we have on the contrary, enflowered it, permitted it to bloom and caused it to display its richness and power as a symbolizing process." 11

12Rather than considering any historical aspects of Adams's message or its different receptions over time, White is interested in the sheer, ahistorical display of the symbolizing process itself. He also holds that the principal task of intellectual history is to focus on such processes of meaning production, whereas other branches of history may concentrate on the "exchange and consumption" of meanings in terms of economy, politics, social thought, and warfare. ${ }^{12}$ But why should intellectual history not be about, say how the American founders' "exchange and consumption" of opinions turned into a common decision to fight for independence or about their entirely different exchange of opinions about the Constitution? As research about the past, even intellectual history must contend with particular occurrences, even if their outcome may not fit the big picture: perhaps the best political pamphlet was ignored; perhaps the intended effect never occurred; perhaps the good guys lost.

13 None of this is to claim that the linguistic aspects of history writing are insignificant. Consider the old witticism about celebrating the most unassuming selfmade man in all American history: "President Abraham Lincoln was born in a tiny Kentucky log cabin, which he had built with his own hands." Even the opening clause, "President Abraham Lincoln was born," is anachronistic, since it took quite a while for 
this newborn to become President of the United States. Yet, as linguistic studies experts insist, discourse is more than a sentence writ large: it is a complicated process of meaning production, which may rest on poetic and rhetorical uses of language, just as much as on sheer logic. ${ }^{13}$ Many historical concepts arise from mere hindsight: the Renaissance, in its basic meaning of a great revival, cannot be grasped without the notions of the ancient, Greco-Roman civilization and the more or less retrograde image of the Middle Ages. The very title, the Middle Ages, indicates its function as linking the other two. Regardless of whether the prevailing image of the Middle Ages should be dark or sunny, one can be absolutely certain that the Middle Ages never had any impact on the ancient era. This much we know about causality in history, and this is practically all we know about it. ${ }^{14}$

14The fact that causality never functions backwards in history is not as self-evident as one might wish it to be. Consider the claim that "human beings can will backward as well as forward in time," as Hayden White remarks about Fredric Jameson's view of history..$^{15}$ True, we tend to see things differently when looking at them from a new (even if only historical) perspective. This notion of willing backwards in time is also the fundamental presumption behind the time-honored notion that every generation writes its own history. The inherent danger of this view is its less often stated, but widely held corollary that every new generation sees the meaning of history better than the previous one, because the previous generation failed to see what its own present truly anticipated. Again, we encounter the notion of history as a grand narrative, gradually unfolding its own meaning, be it the Marxian conception of production relations as the true mold of world history or Obama's set of values comprising the "quiet force of progress" in American history.

15To further illustrate this point, let me cite Allan Megill's summary of why modern historiography tends to be antithetical to any master narrative. First of all, the modern historical view would dismiss the early modern notion of biblical history as well as what is often considered its direct inheritor, the Enlightenment era's notion of progress as something that lent coherence to the apparent chaos of the entire preEnlightenment past. Secondly, historians do not subscribe to the Rankean view of an extra-human rationale behind history as a coherent whole, even if the ongoing research cannot yet quite grasp it. Thirdly, many historians would be skeptical about the shift toward the view of J.G. Droysen and R.G. Collingwood that the coherence of history may only derive from the validly defined methodological boundaries of history as an academic discipline-thus comprising a methodologically coherent region within which the professional historian works. What position toward the disciplinary character of history as a whole, then, would be tenable today? The fourth position holds that most probably no coherence can be found, although any clear-cut statement that history has no coherence is vulnerable as well, because it claims to know too much. 16

16Even though narrative is by definition temporal, it may play with the linear conception of time, given that the end determines the actual meaning of the whole story. History does not have this freedom. In purely narrative terms, it is only the appearance of Jesus Christ in the New Testament that gives the prophets of the Old Testament their Christian meaning as predecessors of the true Messiah, whose coming they correctly prophesized (albeit the Jewish reading of all this would be very different). The difference between historical and mythic thinking arises with the 
linearity of causes and effects. One may conjure the spirits of one's forefathers in a ritual so as to experience their presence anew, and yet subscribe to the fundamental linearity of human time in terms of recognizing the forefathers as something other than the living and the not yet born. Celebrating the wisdom of the American founding fathers in every presidential inaugural speech or celebrating the birth of Christ every Christmas does not make those celebrations identical in their historical meaning. Meanings in history arise from the temporal, or occasionally the spatial, distance between any two phenomena of the past.

\section{History and Temporality}

17As for the even deeper layers of narrativity inherent in the meaning production itself, let us shift to the distinction between temporality and history writing. In Paul Ricoeur's view, temporality (or "the structure of time") appears to be "the content of which narrativity is the form." ${ }^{17}$ Simply put, one may think of temporality as denoting the idea of viewing time as an eternal present, something that always transcends the past but does not yet reach the future. Our experience of this "eternal now" consists in our constant orientation to the future. Everything we do is future-oriented. This future orientation does not result from our knowledge about the future, but only from our expectations: Perhaps when going to pick up my first cup of coffee in the morning, I realize that I have forgotten to push the power button of my coffeemaker. I cannot undo my error that has already taken place, I need to press the button to get my morning coffee in a future different from the one I expected. Hence, the standard, tripartite notion of time as consisting of the past, the present, and the future is best grasped through the notion of the present as distinguished from the past that one cannot change and one's present as that which gains its very meaning via one's orientation to the future. It is this notion of constantly advancing time that lends support to such metaphysical notions as "every great historical narrative" simply "is an allegory of temporality." 18

180 ne traditional way of grasping the notion of constantly advancing time is the cyclical view, which considers the rotary motion as the fundamental image for meaningful changes. This rotary motion takes the form of a cycle, stretched over the linear line of time. Even the ultimate, or at least the bleakest, Christian image of meaningful time can be viewed as cyclical rather than as linear. After the Fall of man human history is but a series of futile efforts to redeem Adam's initial mistake. The story thus comprises a single cycle-a rotary motion back to the divine Redemption. ${ }^{19}$ The Second Coming will bring history to its conclusion, and history, in its meaningmaking rotary motion, closes precisely where it began. Salvation to true believers and judgment for the sinners ensues.

19 No historian is in the position to say that this is not so, although for secular thinkers it may appear just as evident that human history will end in some utter human failure to come to terms with our natural circumstances. Yet, no imagined end of history can function as the standard for writing it in the very midst of the story itself, particularly as we cannot know if history embodies a reasonable story to begin with. This is why professional historians today prefer to keep their storyline open so as not to use it as an explanatory framework for any particular historical event. 
20The most frequent mistake made about cyclical history concerns its presumed determinism regarding individual experience of time. The ancient notion of seeing the world in terms of monotonous yearly cycles of sowing and harvesting was far from refuting the constant advance of human time. The point was only that no matter how obviously this year's harvest differed from the previous one the change never appeared as permanent. This is the basis for the ancient notion of history as magistra vitae, precursor of life. The perhaps most renowned formulation of the sociopolitical aspects of this notion is the Polybian conception of the transience of governments, centered on the conception of civic virtue and its natural erosion over time. In its most classically republican version, it held that every virtuous monarchy would inevitably fall into a corrupt tyranny, then would follow a virtuous aristocracy and a corrupt oligarchy, then a virtuous republic and then a corrupt mob rule-all this to the effect that a new virtuous monarchy would begin the three-fold cyclical movement again.

21This is why the early modern understanding of the term "revolution"-arising from the notion of something revolving and hence related to rotary motion-referred rather to a return to the olden times than to any genuinely innovative break with the past. ${ }^{20}$ Yet, for an individual immersed in such a cyclical political history, change could appear as genuinely contingent. Contingency entered the view in the famous imagery of the Roman Goddess, Fortuna. She could rotate her wheel of fortune slowly or quickly to the effect that a corrupt polity could last just as easily for a couple of months as for two centuries. No one knew which precise phase of the cycle it currently occupied. This is why the ancient statesman remained in absolute uncertainty about when exactly it would stand to reason to try to topple a corrupt regime. Even if all history consisted in rotary motion, an individual could not foresee at what precise point of the future the next meaningful (although only cyclical) change would occur.

22In the midst of the American Revolution, Thomas Jefferson spoke of it as "a rebellion" aiming simply at "a restoration of our just rights." ${ }^{21}$ Viewed from a classical republican perspective, the American founding generation was simply lucky: their rebellion proved successful. Given their fast division into competing Federalist and Democratic parties after the founding, it is certain that they never shared one comprehensive notion of what American republicanism should look like.

23Even a political conservative is future-oriented in his constant longing for the revival of yesterday's values in tomorrow's world. Indeed, a tradition cannot be neutral, because its actual meaning resides in its capacity to guide us toward the future. A neutral tradition would be no more than a taboo, which typically embraces norms the purpose of which no one can explain any more. Neither should one view every tradition as inherently reactionary. Since the Enlightenment era, one of the most sacred Western traditions has been the reverence toward the dramatic development of empirical, selfcorrecting scientific thought. Even the hard-core progressive, however, must submit to the notion that insofar as knowledge accumulates, every present must deal with incomplete knowledge. Given the necessity of dealing with incomplete knowledge, the safest epistemological tenets of historiography are comparatively simple. As human beings, we all live in constantly advancing time, which keeps our future open just as it closes alternative options of the past. Given that no one can see at the end of history, there is no way to say that it makes any sense even as a narrative. While historians have the privilege of working with hindsight, there is no hindsight of the future. From the historian's perspective to the past, however, everything is linear. 
24Karl Marx may provide an illuminating example of how to separate one's experience of time from one's image of history. Marx's viewpoint is twofold: the utopian aspect of Marxism lies in its view of an entirely different post-revolutionary socialist future compared to what Marx saw as the known plot of the past, namely that the forces of production (the base) have always been ahead of the political ordering of society (the superstructure). The continuous tension between the two had been the source of conflict throughout human history. This conflict the socialist revolution was supposed to resolve in the future. Scholars still disagree as to what extent Marx's vision of the future was as predetermined as his view of the past. In other words, one may, or may not view Marx's historical thinking as based on his own metanarrative.

25This is why it is useful to distinguish a historical explanation of the actual causes of an event from its meaning in its own time and from its significance (or insignificance) for us in the present. Most important, this also calls for distinguishing politics from historiography. Politics is always about analyzing the present situation in order to gain a better future. History is about the past.

\section{History and Politics}

26Whatever the world-historical repercussions of the American Revolution, it did not alter the fundamental characteristics of politics as a struggle over the future. Soon after the Revolution Jefferson found himself entangled in a constant fight with Alexander Hamilton, not over the past, but over the American future. President Obama similarly focuses on the future in arguing that we need to look forward rather than backward. But our view of history has definitely changed since Jefferson's time, just as Jefferson's view was different from that of Polybius.

27Jefferson thought that history has a direction toward a better future, which the "primitive" Native Americans would probably never achieve on their own because their "steady habits permit no innovations, not even those which the progress of science offers to increase the comforts, enlarge the understanding, and improve the morality of mankind."22 This is how he invoked the future in his famous 1824 letter to William Ludlow: "Where this progress will stop no one can say. Barbarism has, in the meantime, been receding before the steady step of amelioration; and will in time, I trust, disappear from the earth." ${ }^{23}$ Jefferson's vision, however, never had to confront such characteristically apocalyptic concerns of our postindustrial age as climate change, worldwide pandemics, or the spread of weapons of mass destruction. Jefferson's belief in historical progress can be assessed regardless of such concerns. A belief in the same today means subscribing to an entirely different claim.

28 Politics demands defining the present as somehow distorted; otherwise no political agenda could arise. In history, it is unwise to make too precise claims about the present, because we are apt to disagree politically on where we are, and therefore on what direction to take next. It is just as important for the practicing historian to discern the genuinely political aspects of the past as it is for a politician to politicize things that need politicization. One may discern a number of political meanings behind the famous 1954 Supreme Court decision of Brown v. Board of Education, given that the Court broke with the central common-law principle of relying on precedents and simply nullified the infamous 1896 "separate but equal" decision, thus also providing legal backup for the entire 1960 s civil rights movement. The fundamental 
characteristics of public policy became an issue during the 1970s debate about compulsory busing of children to a distant school in order to put the desegregation of schools into effect. Were children to be used for such a political purpose?

29The recent debate about the rights of homosexuals to equal marriage also questions the border we tend to assume between the public and private spheres of life, the assumption that private is apolitical. One can always question a societal norm by bringing forth its implicit power claims: the traditional, heterosexual understanding of what kind of intimate relations can be recognized as marriages appears simply as a power claim over all those who would recognize homosexual marriages. Until the claim for recognizing homosexual marriages was made, there was no political conflict about it. Hence, not everything is politics, but anything can be politicized. But any claim that defining the past is as political as defining the present seems to support the metaphysical notion that we are all living some inherently meaningful metanarrative.

30The lure of metanarratives is strong among historians themselves. The advocates of the currently fashionable history of globalization appear to view the growing interconnectedness of the world cultures as such a fundamental characteristic of the world that we should rewrite all our histories to accommodate to this trend. A new master narrative is born. Again, the focus is not where it should be: it is on politics rather than on history, more on the present than on the past. Given the very possibility of politicizing normalcy by questioning its implicit power claim, it is important to remember that we do not share a common view about where we are right now. As the 9/11 attacks well prove, globalization may also serve to intensify the potential enmities among us.

31The uncritical advocacy of globalization as the explanatory framework for meaningful historiography recalls Francis Fukuyma's approach to history in his famous The Last Man and the End of History (1991). Fukuyama's thesis was not exactly that history is at its end, but that the collapse of the Soviet experiment proved that the search for the most feasible political ordering of society is over. The conclusion was that democracy with individual rights in a free market economy would prevail. That interpretation hardly enriched our understanding of history: in light of the recent rise of ultra-nationalism, populism, anarchism, and religious fundamentalism all over the world, one may well ask if we have any idea at all of where we are actually heading.

32 When history is at its end, there is no one left to ponder its meaning. Consider the imagery of "the last man" in Fukuyama's title in terms of, say, scientific search after truth. Let us imagine that at the end of days there appears a physicist, who solves all the problems of the string theory and hence grasps the entire character of existence itself. Should this "last of the Mohicans" have a son, who not only fails to grasp his father's insights, but also outlives him (unlike Uncas), are we to conclude that the history of man results in nothing but ignorance? History is not about the end, it is about human events over time and about human experience of that time.

33Johann M. Neem's recent defense of national history in his article "American History in a Global Age" draws on the notion that globalization is nothing but a new master narrative, whose problem is its uncritical attitude to the excesses of global capitalism. Yet, given that, "like nationalism, cosmopolitanism is a narrative project," ${ }^{24}$ Neem argues only for a new national master narrative by which to keep critical distance from the cosmopolitan one. Given that "history is a civic enterprise," it appears to him a mere matter of fact that "the moral force" of even transnational 
narratives "depends on their readers' nationalism." ${ }^{25}$ No wonder, Neem's new narrative resembles the old one: The founders, believing that "the nation must embody universal values," built "the roof" and the rest of American history is about building "the walls" for national liberalism. ${ }^{26}$ The comparative analysis behind this view is strikingly simplistic in its appeal to the present: violence "continues to wreak havoc" in those non-American "parts of the world where both nationalism and liberalism remain weak." ${ }^{27}$ Regarding history writing, Neem holds that "forming collective identity is not the only or even necessarily the primary purpose of professional history," 28 which is only to say that it is necessarily one of its purposes, if not the primary. Neem, in fact, contextualizes the notion of seeking truth of the past within totally extra-curricular kinds of concerns for nationalistic identity building. He knows the significance of what national history may reveal prior to the research he is apparently promoting.

\section{Explanations and Significance}

34Letting go of the metanarrative does not entail losing the concept of historical context. For the classic, Rankean school historical contextualization would be a comparatively simple matter of situating a given phenomenon within the circumstances of its own time. Various modes of historicism subscribe to this view, among them the radical position that there are no other truths than historical ones. ${ }^{29}$ Even this we do not know. It is good not to lose sight of the possibility of truth being something else entirely. Yet, the problem of historical contextualization solves itself if we think of history simply as a discourse among historians' different accounts of a given past phenomenon.

35Bluntly speaking, historical contextualization can be viewed as a matter of a historian either agreeing or disagreeing with one's colleagues about the historical circumstances of a phenomenon under question. Collingwood's old thesis that "all history must be consistent with itself" may well hold true, given that any two mutually exclusive accounts of a particular past phenomenon cannot both be acceptable. ${ }^{30}$ Genuinely innovative views tend to arise when a historian takes a fresh view of the circumstances rather than of the event itself. Alfred Crosby's The Columbian Exchange (1972) became one of the initiators of environmental history in studying the huge impact of the European invasion to America from 1492 onwards, but not by focusing on politics, disease, and warfare. Instead, Crosby studied how the Americas changed as natural environments and as cultural landscapes thanks to the introduction of so many new plants and animals as well as the consequent extinction of many others. ${ }^{31}$

36Similarly, Pekka Hämäläinen's award-winning The Comanche Empire (2009) provides a wholly new perspective on the actual role of one Native-American nation in Western history by offering a convincing set of explanations for what made the Comanche "confederation" so important and successful compared to other Great Plains Indian nations, the Texans, and the Spanish of that era. That Hämäläinen also brings to the fore the ways the Comanches secured their access to carbohydrates alongside their protein-rich food as nomadic hunters complicates matters, however, since the reader is not informed which potential competitor of the Comanche empire failed to secure equally healthy nutrition and to what effect. ${ }^{32}$ Viewing every possible explanation about a given topic as methodologically equal would presume not only that reality is essentially holistic, but also that knowledge about it must be equally so. Just as we 
cannot presume a metanarrative, we do not know whether everything is in a meaningful sense related to everything else.

37To be sure, Hämäläinen's remarks about nutrition do not contradict any other explanations he offers. And the central positive outcome of his approach results from seeing power relations as a much more comprehensive issue in history writing than historians of the American West generally admitted before his book. The idea of integrating his saga of this empire into some larger "metanarrative" 33 of American history as some commentators have suggested, is unlikely to help us in determining the quality of his historical research. What would we benefit from further integration of this saga into some metanarrative, except perhaps to subscribe to some such an absurd claim that these people were on the "wrong side of history," because their empire fell?

38 An analytic approach to history may well call for counterfactual thinking and yet have nothing to do with so-called counterfactual history. The Journal of American History recently published Gary J. Kornblith's article, "Rethinking the Coming of the Civil War: A Counterfactual Exercise." The author aims to question the inevitability of the Civil War in 1861-65 by positing "the absence of the Mexican-American War" in 1846-48. ${ }^{34}$ This entire "exercise" consists of reasoning on the basis of what we know not to have been the case. One would get the same amount of historical knowledge by stating that "in the absence of the American founding, no outbreak of the Civil War in 1861." The practitioners of future studies must reason with probabilities because they study the possible future. The so-called "counterfactual" history is not history, because it does not study the past. By contrast, counter-factual analysis can be used in history, for in history there is always a better reason for what happened than for what did not.

39 Counterfactual analysis, in Allan Megill's well-known formulation, holds that a cause $C$ is an efficient cause for A to turn into B, provided that without C, B would not have arisen, all other things being equal. Let us think of the best available explanation for the Civil War in light of this. Even if committed to the view of slavery as the ultimate reason for the war, one might think of timing as an important factor. Given that the war erupted so soon after the 1860 Presidential Elections, one could begin by seeking the reasons why Stephen Douglass, J.C. Breckinridge, and John Bell stood as presidential candidates alongside Lincoln. None of them intended to split the southern vote to help Lincoln win the presidency. Given that shortly before the war there were numerous meetings held to solve the situation peacefully, even the Southern leaders appear to have had a living attachment to the Union. This approach might provide one with new hindsight about the point at which no return was possible, perhaps even earlier than April 12, 1861, when the first grenades began flying to Fort Sumter.

40In seeking the Southerners' ultimate reasons for seceding from the Union in the Spring of 1861, there is no escape from the notion that slavery was among them, alongside the decades-long debates over custom duties; the gradual formation of a distinct Southern identity from at least the late 1840s onwards; and competition over the markets of the West. Perhaps the most important factor was the ominous loss of southerners' property value in slaves (dependent on expectations of growth), should the North prevent the expansion of slave economy to the West. No abolitionist, of course, suggested prohibiting the expansion of free labor cotton cultivation to the West. Slavery had been part of Southern society over two hundred years, but only very shortly before the war did it come to be viewed as the reason for secession from the Union. ${ }^{35}$ Perhaps the industrial revolution might be a contributing factor. As historian 
Gerald Gunderson has pointed out, thanks to the telegraph, increasing number of newspapers, better transportation, and general economic growth, "Americans not only had more income with which they could choose to end the unwholesomeness they saw in slavery, but they were reminded of it far more often as well." 36

41The point is not that slavery alone caused the Civil War. The point is that without slavery the other reasons would not have caused it-at least not at the time it erupted. One may speculate which particular aspect of slavery was the crucial one, but certain it is that "without slavery, no Civil War in 1861-65." In other words, slavery is a necessary reason for the Civil War. One might take a step further and ask if slavery was the sufficient reason for the war. The sufficient reason always belongs to the group of necessary reasons, although it may also be a particular juxtaposition of them. To illuminate the case, one might argue that the link between the Civil War and slavery is stronger than that between lung cancer and smoking: while smoking may be the decisive reason for a particular smoker to get lung cancer, it is neither the sufficient nor even a necessary reason of lung cancer, because nonsmokers also get it. Hence, one should not confuse smoking with even the juxtaposition of a number of necessary risk factors that explain lung cancer. By contrast, explaining the outbreak of the Civil War in 1861 without slavery is impossible.

42 None of this is to argue that the Civil War was not a "war between the states." Neither was slavery the only subject of controversy within the Union pertaining to the erstwhile, Jeffersonian doctrine of states' rights. Moreover, the Civil War did not solve all the issues related to states' rights. Religious freedom was one of those issues, for the national Constitution guaranteed only that the national government would not restrict religious freedom. Even as the author of Virginia's law of religious freedom, Jefferson appears to have never suggested that other states could be compelled to follow suit. Notably, it was only in 1961 that the U.S. Supreme Court ruled out Maryland's right to demand religious oaths from its civil servants.

43As for the issue of slavery, Jefferson opposed the early Missouri compromise in 1819 by arguing that the northern abolitionists turned a simple juridical definition of civil rights belonging exclusively to the states into a controversy over the Union. Lincoln himself swore to save the Union whether it demanded freeing all the slaves or freeing none. Thus, it was only in 1865 that all northern states were required to abolish slavery, New Jersey being one of the very latest to do so. It was as late as 1969 that Virginia was compelled to let go of its prohibition of interracial marriage. Was this prohibition a mere remnant of the antebellum laws to consolidate slavery as a racial institution? It was not, because the entirety of post-bellum Jim Crow legislation aimed to restore racial boundaries in lieu of slavery. ${ }^{37}$ Neither did these laws have anything to do with Jefferson's legacy, for his solution was to deport the entire African-American population from the Union. There are clear historical discontinuities between Jefferson's position and the later ones, which cannot be explained away, because the events in between matter.

44Seeking truth about past is different from turning historical facts into a rationale for present-day conceptions. In disagreeing with the 2012 Supreme Court majority ruling on Arizona's powers to restrict immigration, Justice Antonin Scalia drew on Jefferson's and Madison's two hundred years old statements about states' rights to restrict immigration. In addition, Scalia viewed Samuel Pufendorf, a German expert in natural law from the late 17th century, as an authority on the issue. ${ }^{38}$ Unlike Jefferson, 
Pufendorf was not a slaveholder. He was not even a racist, for he thought it unfortunate that slavery was abolished as a social institution among the Europeans. ${ }^{39}$ Scalia is an advocate of the time-honored constitutional doctrine of original intent. The doctrine is simply ahistorical: it looks for the founders' original intent even on issues they never imagined possible. The Civil War permanently changed the balance between states' rights from anything the founders had ever had in mind, just as it destroyed Jefferson's vision of bringing German immigrants to replace the slaves whom he would have deported from the Union. Again, the events in between matter. It is difficult to imagine a serious study of American constitutional history without subscribing to the notion that the meaning of the Constitution has indeed altered over time. None of this is to claim that only discontinuities matter in history. Should a historian prove that there was no essential break where all others have assumed otherwise, that would also be a valid research result.

\section{Conclusion}

45As argued above, there is no necessary connection between the perhaps inescapably narrative character of history and the historian's absolute commitment to the linearity of time in historical explanation. Narrative may play with the concept of linear time, its ending determining the story's actual meaning; history may not. In history, causation never goes backwards in time. Neither does history inform us about the future.

$46 \mathrm{As}$ an art of recounting the past, history is about examining a particular past event or phenomenon-be it a war, a famine, a debate, a pattern of behavior, an economic cycle, or a trend of thought-and explaining it as a result of reasons predating it. Stuck inside the constantly advancing time like all other human beings, a historian cannot explain an event by its consequences, even if those consequences rather than the event itself are what make it significant enough to be written in a history book. The significance of an event can be found in the present alone, and no matter how important a given historical event may now seem that may change in the unforeseeable future.

47The presumption that history may tell us something significant in the present is too often associated with our presumably shared understanding about where history has brought us. The existence of such an understanding is vastly exaggerated. Just as in the past, people still have tremendously different ideas about the current human condition. This is why one should avoid politicizing history writing as a "civic enterprise" in itself. The line between the historian's job proper and the act of politicizing the past for one or another presumably good purpose is thin. Yet, it is there. Ending American slavery is neither a political, nor a moral problem for us. We know how it came to its end. As Aristotle once put it, no one deliberates about the past. Only present policies can be put to a genuine moral test, and even justifiable occasions of violence can be viewed as resulting from a political failure, given that politics is conflict solving in peaceful means.

48Thus understood, the main limits of historical research are practical ones, such as the size or complexity of the questions most useful to ask about the past in order to turn past phenomena into history: that is, to provide historical knowledge. None of this is to argue against narrative accounts of the past. The central formal requirement of a 
historical research project is only that it begins with a research question and ends with the answer to that particular question. The minimum requirement is the same as in all academic disciplines: one must avoid so meaningless a research that "it is not even wrong," as physicist Wolfgang Pauli famously stated on a study paper.

49Despite the popular witticisms that "the worst thing about history is that every time it repeats itself, the price goes up," there is no way to prove that history repeats itself. The reason is that we have no common denominator enabling us to define any two temporally distinct phenomena as identical without presuming that absolutely nothing of consequence happened in between. Just like the present, the past is a huge mess of causes and effects. Earthquakes, tsunamis, floods, draughts, and other natural occurrences have dramatically affected history. As for deliberate changes, innumerable, conscious and unconscious, intentional human acts have collided with each other and produced events that probably no single agent intended exactly as they eventually took place. This is also why one may well hold that history teaches us nothing-besides, perhaps, historical thinking itself.

5olf history teaches us nothing but historical understanding, what is the use of it? Perhaps its only use is to remind us to regard the essentially unforeseeable future with a historical consciousness rather than with one or another mythical notion of a foundational truth-be that the American Constitution or the first book of Genesis. What other use should history have? For a great many people, history speaks only to our recurrent failures to resolve our conflicts peacefully, and to the comparative inefficacy of our very best intentions. Insofar as history may appear elevating to some of us, perhaps the lesson is, to paraphrase J.D. Salinger, that neither we, nor our predecessors, were put here to die for a reason, but to live for one.

\section{NOTES}

1. The author wishes to thank Allan Megill and Matti Peltonen for their valuable critical comments. The views expressed are all mine.

2. See Alun Munslow, A History of History (London: Routledge, 2012), 44. I thank Ilona Pikkanen for bringing this quotation to my attention.

3. On history's meaninglessness, see Hayden White, The Content of the Form: Narrative Discourse and Historical Representation (Baltimore: The Johns Hopkins University Press, 1990), 72; To an extent, the question about the ultimate meaning of history as a metanarrative can be answered by a historian's attitude to it: for an idealist, history manifests human progress; for a cynic, it appears as a sheer tragedy of the continuing degeneration of the human race; and for a skeptic, it unfolds as a great farce with no substantial meaning whatsoever. Given White's ruminations about these, not mutually exclusive, attitudes to history, one may read him as arguing simply (though in a particularly complicated way) that we have no reason to believe that history has a purpose.

4. White, The Content of the Form, 2. White states that "Historians do not have to report their truths about the real world in narrative form. They may choose other, nonnarrative, even antinarrative modes of representation, such as the meditation, the anatomy, or the epitome. Tocqueville, Burckhardt, Huizinga, and Braudel ... refused narrative in certain of their 
historiographical works." To be sure, in his other writings, White extends the notion of narrative to cover practically all of the other forms as well.

5. One of the most amusingly distorted uses of the past I have ever seen is that of Harry Jaffa, who holds that "had Aristotle been called upon, in the latter half of the 17th century, to write a guide book for constitution makers, he would have written something very closely approximating Locke's Second Treatise. For he would have recognized instantly those differences from his Politics that prudential wisdom required, in the world of Christian monotheism." Essay by Harry V. Jaffa, "Aristotle and Locke in the American Founding," Claremont Reviews of Books (Winter 2001 Issue), 10; Pdf-file (accessed Aug. 11, 2014) at http://www.unz.org/Pub/ ClaremontRevBooks-2001q1-00010

6. See for this concept, Constantin Fasolt, The Limits of History (Chicago: Chicago University Press, 2004), xiii.

7. Barack Obama, Inaugural Speech, Jan 20, 2009, Miller Center, University of Virginia, Presidential Speech Archive (accessed July 5, 2011) at http://millercenter.org/scripps/archive/ speeches/detail/4463

8. For the sake of clarity: I would personally embrace an even more thorough health care reform, just as did President Obama himself initially, but my political stance has little to do with what I think is interesting in American history, whether considered as a progressive or a regressive entity in itself.

9. White, The Content of the Form, 16.

10. For quotations, see Ernest Gellner, Nations and Nationalism (Ithaca: Cornell University Press, 1983), 51, 55.

11. White, The Content of the Form, 206-209.

12. White, The Content of the Form, 209.

13. White, The Content of the Form, 39-40.

14. This is why I would dismiss such mysterious claims as that of Arthur C. Danto, who states that, "If the future is open, the past cannot be utterly closed." Whatever Danto's actual meaning here, one may distinguish between any such an utterly closed past and our constantly changeable image of it. See Arthur C. Danto, Narration and Knowledge (New York: Columbia University Press, 1985), 196.

15. White, The Content of the Form, 150.

16. Allan Megill, "'Grand Narrative' and the Discipline of History" in A New Philosophy of History, ed. Frank Ankersmit and Hans Kellner (Chicago: University of Chicago Press, 1995), 165.

17. White, The Content of the Form, 54.

18. On Ricoeur, White, The Content of the Form, 181.

19. See Pasi Falk's intriguing article, "The past to come" Economy and Society, Vol. 17 (3, 1988), 374-394, esp., 379.

20. See, for example, Hannah Arendt, On Revolution. New York: Viking Press, 1963, 35-36.

21. TJ to John Randolph, Aug. 25, 1775, Merrill D. Peterson (ed.), Thomas Jefferson Writings (New York: The Library of America, 1984), 749.

22. Thomas Jefferson to John Adams, June 11, 1812, Lester J. Cappon (ed.), The Adams-Jefferson Letters: The Complete Correspondence Between Thomas Jefferson and Abigail and John Adams (Chapel Hill: University of North Carolina Press, 1959), 307.

23. Thomas Jefferson to William Ludlow, Sept. 6, 1824, Peterson (ed.), Thomas Jefferson Writings, 1496-1497.

24. Johann N. Neem, "American History in a Global Age," History and Theory, 50 (Feb. 2011), 41-70, quote, 59.

25. Ibid., pp. 52, 70 .

26. Ibid., 56, 64 .

27. ibid., 70 . 
28. Ibid., 70 .

29. For a good introduction to these problems, see for example, Frank Ankersmit, Meaning, Truth, and Reference in Historical Representation (Ithaca, NY: Cornell University Press, 2012), 10.

30. For the Collingwood quotation, see Megill, "Grand Narrative," 163.

31. Alfred Crosby, The Columbian Exchange: Biological and Cultural Consequences of 1492 (Westport: Greenwood Press, 1972).

32. Pekka Hämäläinen, The Comanche Empire (New Haven: Yale University Press, 2009), 347-349. On carbohydrates, see, 352.

33. As Ty Cashion writes, "Comanche Empire ... should significantly influence future metanarratives, whether they include all or parts of Texas, the West, the Borderlands, or even general histories of the United States and Mexico." Ty Cashion, "The Comanche Empire (review)," The Journal of Military History, Vol. 73, (2, 2009), 647 (emphasis added).

34. Gary J. Kornblith, "Rethinking the Coming of the Civil War: A Counterfactual Exercise," in The Journal of American History, Vol. 90, No 1 (June 2003), 76-105.

35. For a classic analysis of the causes of the Civil War, see the subchapter "The American Civil War: the Last Capitalist Revolution" in Barrington Moore Jr., Social Origins of Dictatorship and Democracy (Harmondsworth: Penguin, 1973), 111-158.

36. Gerald Gunderson, A New Economic History of America (New York: McGraw-Hill, 1976), 264.

37. For this important distinction between slavery and the general disfranchisement of African Americans in the late nineteenth century as part of the project of Southern whites to restore "race control," see James Oakes, Slavery and Freedom: An Interpretation of the Old South (New York: Vintage Books, 1991), 204.

38. For Antonin Scalia's opinion on Arizona v. United States, 567 as of June 25, 2012 see the U.S. Supreme Court website (accessed, June 26, 2012), http://www.supremecourt.gov/

39. See on Pufendorf's rather surprising stance on slavery, Kari Saastamoinen, "Pufendorf on Natural Equality, Human Dignity, and Self-Esteem," Journal of the History of Ideas, Vol. 71 (1, 2010), 44.

\section{ABSTRACTS}

This paper argues that we can let go of the conception of narrative history, not because we know history to be something else entirely, but because the conception too often leads to needless confusion about the methodological basics of historical research among both history students and professional historians themselves. One may view history simply as knowledge of the past and as an ongoing discussion between historians (and other interested parties) over the best account of any given past phenomenon. Given that we politically disagree on where exactly history has brought us, the safest epistemological position for a practicing historian is that the past is just as messy as our own present in which we attempt to find political solutions for a better future. Rather than clinging to any inherently narrative character of history, or of historical representation, the practicing historian may well concentrate on explaining the meaning of a given phenomenon in the past and its possible historical significance for the present, and at least attempt to distinguish between these two. 
INDEX

Keywords: cyclical history, globalization, Hayden White, historical narrative, linearity, politics, temporality

\section{AUTHOR}

\section{ARI HELO}

University of Oulu 